\title{
Needs and opportunities in mineral evolution research
}

\section{Citation}

Hazen, R. M., A. Bekker, D. L. Bish, W. Bleeker, R. T. Downs, J. Farquhar, J. M. Ferry, et al. 2011. "Needs and Opportunities in Mineral Evolution Research." American Mineralogist 96, no. 7: 953963.

\section{Published Version}

doi:10.2138/am.2011.3725

\section{Permanent link}

http://nrs.harvard.edu/urn-3:HUL.InstRepos:13041346

\section{Terms of Use}

This article was downloaded from Harvard University's DASH repository, and is made available under the terms and conditions applicable to Open Access Policy Articles, as set forth at http:// nrs.harvard.edu/urn-3:HUL.InstRepos:dash.current.terms-of-use\#OAP

\section{Share Your Story}

The Harvard community has made this article openly available.

Please share how this access benefits you. Submit a story.

Accessibility 
3

REVISION \#1 - February 2, 2011*

\title{
Needs and opportunities in mineral evolution research
}

\author{
Robert M. Hazen ${ }^{1 *}$, Andrey Bekker ${ }^{2}$, David L. Bish ${ }^{3}$, Wouter Bleeker ${ }^{4}$, Robert T. Downs ${ }^{5}$, \\ James Farquhar ${ }^{6}$, John M. Ferry ${ }^{7}$, Edward S. Grew ${ }^{8}$, Andrew H. Knoll ${ }^{9}$, \\ Dominic Papineau ${ }^{10}$, Jolyon P. Ralph ${ }^{11}$, Dimitri A. Sverjensky ${ }^{7}$, John W. Valley ${ }^{12}$ \\ ${ }^{1}$ Geophysical Laboratory, Carnegie Institution, 5251 Broad Branch Road NW, Washington, D. C. 20015, USA. \\ ${ }^{2}$ Department of Geological Sciences, University of Manitoba, Winnipeg, Manitoba R3T 2N2, Canada. \\ ${ }^{3}$ Department of Geological Sciences, Indiana University 1001 E. 10th St., Bloomington IN 47405, USA. \\ ${ }^{4}$ Geological Survey of Canada, 601 Booth Street, Ottawa, Ontario K1A OE8, Canada. \\ ${ }^{5}$ Department of Geosciences, University of Arizona, 1040 East $4^{\text {th }}$ Street, Tucson, Arizona 85721-0077, USA. \\ ${ }^{6}$ Department of Geology and ESSIC, University of Maryland, College Park, Maryland 20742, USA \\ ${ }^{7}$ Department of Earth \& Planetary Sciences, Johns Hopkins University, Baltimore, Maryland 21218, USA. \\ ${ }^{8}$ Department of Earth Sciences, University of Maine, Orono, Maine 04469, USA. \\ ${ }^{9}$ Department of Organismic and Evolutionary Biology, Harvard University, Cambridge, Massachusetts 02138, USA. \\ ${ }^{10}$ Department of Earth and Environmental Sciences, Boston College, Chestnut Hill, Massachusetts 02467, USA \\ ${ }^{11}$ mindat.org, 81 Woodcote Grove Road, Coulsdon, Surrey CR5 2AL, UK. \\ ${ }^{12}$ Department of Geoscience, University of Wisconsin, Madison, Wisconsin 53706, USA.
}




\section{Abstract}

27 Progress in understanding mineral evolution, Earth's changing near-surface mineralogy through

28 time, depends on the availability of detailed information on mineral localities of known ages and 29 geologic settings. A comprehensive database including this information, employing the 30 mindat.org website as a platform, is now being implemented. This resource will incorporate 31 software to correlate a range of mineral occurrences and properties versus time, and it will thus 32 facilitate studies of the changing diversity, distribution, associations, and characteristics of 33 individual minerals as well as mineral groups. The Mineral Evolution Database thus holds the 34 prospect of revealing mineralogical records of important geophysical, geochemical, and 35 biological events in Earth history.

39 Keywords: philosophy of mineralogy, database, isotope geochemistry, origins of life, mineral 40 data

*E-mail: rhazen@ciw.edu 


\section{INTRODUCTION}

44

45

46

47

48

49

50

51

52

53

54

55

56

57

58 could be addressed by employing such a database. 


\section{EXAMPLES OF MINERAL EVOLUTION RESEARCH}

62

Many authors have already presented data on the temporal variation of individual or collective mineral properties without invoking the term "mineral evolution." Although motivated by different questions, and implemented using varied types of geochemical and mineralogical data, these studies exemplify both the promises and challenges of mineral evolution research.

\section{Isotope Compositions}

Geochemists have long recognized the importance of changing isotope ratios through time as records of major geophysical, geochemical, and biological events in Earth history. In the case of sulfur isotopes, changes in the range of $\delta^{34} \mathrm{~S}$ values with time have been linked to the evolution in the concentration of sulfate in the oceans and changes in the relative amounts of sedimentary pyrite formation in the marine environment and weathering on the continents (Monster et al. 1979; Canfield et al. 2000; Habicht et al. 2002; Berner 2006; Schroeder et al. 2008). Temporal changes in the range of $\Delta^{33} \mathrm{~S}\left(\approx \delta^{33} \mathrm{~S}-0.515 \delta^{34} \mathrm{~S}\right)$ have been tied to changes in atmospheric composition, specifically to the time when the accumulation of oxygen in the Paleoproterozoic atmosphere eventually led to conditions in which the production and preservation of massindependent fractionations (MIF) of sulfur isotopes by photochemical reactions were inhibited (Farquhar et al. 2000, 2001; Pavlov and Kasting 2002; Bekker et al. 2004; Papineau et al. 2005, 2007; Ono et al. 2006, 2009; Domagal-Goldman et al. 2009; Guo et al. 2009; Hofmann et al. 2009; Halevey et al. 2010). Small sulfur isotope MIF are also used to track changes in the ecology of sulfur-metabolizing organisms in Earth's oceans since the rise of atmospheric oxygen (Johnston et al. 2005; Wu et al. 2010). Figure 1, which illustrates the present state of knowledge of the $\Delta^{33} \mathrm{~S}$ record versus time, reveals both the dramatic decrease in the variability of $\Delta^{33} \mathrm{~S}$ after 
$85 \sim 2.4 \mathrm{Ga}$ and the smaller-scale variability that is preserved by sulfate minerals and sulfate trapped

86 in carbonate minerals for the more recent part of the geologic record. The convergence of $\Delta^{33} \mathrm{~S}$ to

87 values within a few tenths of a permil of zero, combined with an expansion in the range of

88 variability for $\delta^{34} \mathrm{~S}$, is interpreted to reflect changes in sulfur chemistry associated with the rise of

89 atmospheric oxygen, the development of a UV-protecting ozone layer, and the onset of

90 significant amounts of oxidative weathering. These observations also corroborate other

91 mineralogical observations that suggest a contemporaneous rise in atmospheric oxygen, the

92 "Great Oxidation Event" (GOE). The presence of anomalous $\Delta^{33} \mathrm{~S}$ in sulfide inclusions in

93 diamond has also been interpreted as evidence for the plate tectonic cycling of sulfur from

94 Earth's atmosphere into the mantle as early as $\sim 3 \mathrm{Ga}$ and then its return to the surface (Farquhar

95 et al. 2002; Thomassot et al. 2009). A goal for future sulfur isotope research will be to correlate

96 geochemical observations with the formation of the specific minerals that preserve these isotopic

97 records and to understand the details of how the MIF signals are transferred from the

98 atmosphere, to the oceans and biosphere, and ultimately to their preservation in the rock record.

99 The mineral zircon $\left(\mathrm{ZrSiO}_{4}\right)$ is especially useful in mineral evolution studies because zircon is

100 a relatively common mineral in coarse-grained siliciclastic rocks, individual zircon grains persist

101 in the rock cycle, it is relatively easy to date individual uranium-bearing zircon grains, and

102 zircon's isotopic and trace element compositions are sensitive to conditions of formation (Ireland

103 and Williams 2003; Valley 2003; Hoskin and Schalteggar 2003; Cavosie et al. 2007; Trail et al.

104 2007). Accordingly, Valley and coworkers (Valley et al. 2005) analyzed oxygen isotopic

105 compositions of igneous zircon grains from 1,200 rocks spanning more than 96\% of Earth

106 history (Figure 2). They found that varying $\delta^{18} \mathrm{O}$ values point to the emergence of crust

107 recycling, crust-mantle interactions, and extensive oxygen isotope exchange between minerals 
108 and the hydrosphere. The zircon data show that oxygen isotope ratios of magmas were generally 109 closer to the average mantle value of $5.3 \pm 0.6 \%$ throughout the first two billion years of Earth 110 history, though with significant positive deviations of up to $2 \%$ that point to the variable

111 involvement of an early hydrosphere. After $2.5 \mathrm{Ga}$, higher $\delta^{18} \mathrm{O}$ values document incorporation 112 of increasing amounts of high- $\delta^{18} \mathrm{O}$ supracrustal material into granitic magmas. These variations 113 indirectly record the processes of surface erosion, sedimentation, and diagenesis that involved 114 isotopic exchange of minerals with water at relatively low temperature. The largest reservoir of 115 high- $\delta^{18} \mathrm{O}$ rocks would have been clay-rich (mature) shales and mudstones, which became more 116 abundant after $2.5 \mathrm{Ga}$ owing to the development of large, stable landmasses and more intense 117 chemical weathering after the rise of atmospheric oxygen, when $\mathrm{CO}_{2}$ became a dominant 118 greenhouse gas in the atmosphere and groundwaters became more acidic due to oxidation of 119 sulfides on the continents (Bekker and Kaufman, 2007; Holland, 2002). Thus the evolution of 120 clay minerals, responding to changes such as the GOE and the expansion of cratons and, 121 therefore, epeiric seas, has affected the composition of magmas and the zircons they contain 122 (Valley et al. 2005). Oxygen isotopes in zircons have the potential to document the end of the 123 Hadean "steam atmosphere" on Earth $(\sim 4.3 \mathrm{Ga})$ and the beginning of the era when more clement 124 conditions became available for the emergence of life (Sleep et al. 2001; Valley et al. 2002, 125 Valley 2008).

126

127 Chemical Compositions

128 The major, minor, and trace element compositions of minerals can provide sensitive 129 indicators of environmental factors at the time of their formation. For example, Nash et al. 130 (1981) and Hazen et al. (2009) catalog several distinct modes of formation of uraninite $\left(\mathrm{UO}_{2}\right)$. 
131 Uraninite with a significant thorianite $\left(\mathrm{ThO}_{2}\right)$ component, which is typical for the late-stage

132 felsic melt segregations such as pegmatites, was stable in an anoxic atmosphere and concentrated 133 in Archean placer deposits. After the rise of atmospheric oxygen, uranium (but not thorium) 134 became soluble in oxidized solutions and precipitated as low Th/U uraninite at redox boundaries, 135 such as contacts with rocks with high concentrations of biologically derived reducing organic 136 compounds.

137 Isotopic and element compositions and elemental ratios in black shales have received special 138 attention because they preserve information about both the nature of terrestrial erosion and 139 deepwater depositional environments (e.g., Anbar et al. 2007; Rouxel et al. 2005; Scott et al. 140 2008, 2011; Partin et al. 2010). These studies, with the exception of that by Rouxel et al. (2005), 141 have focused primarily on bulk shale properties rather than those of specific micro-mineral 142 phases; nevertheless, temporal variations in mineral composition and other characteristics lie at 143 the heart of this effort. Thus, for example, secular changes in the iron chemistry of carbonaceous 144 shales has helped to establish long-term redox states of deep water in the world's oceans. In 145 particular, unusual enrichments in Fe provide evidence for expanded anoxia in the oxygen146 minimum zones of Proterozoic oceans, while the enhancement of siderite instead of pyrite 147 deposition at about $800 \mathrm{Ma}$ points to a decline in the extent of euxinic conditions significantly 148 before the deep ocean became oxygenated (Canfield et al. 2008; Lyons et al. 2009; Johnston et 149 al., 2010).

$150 \quad$ Partin et al. (2010) document both $\mathrm{U}$ concentration and $\mathrm{Th} / \mathrm{U}$ ratios in black shales over 3.5 151 billion years of Earth history. They describe a significant increase in U content in carbonaceous 152 shales (possibly as nano-precipitates of uraninite and $\mathrm{U}^{4+}$-silicates) shortly after the rise of 153 atmospheric oxygen at ca. $2.32 \mathrm{Ga}$ (Bekker et al. 2004). This change was associated with the 
154 mobilization of $\mathrm{U}^{6+}$, which is easily transported in oxidized aqueous complexes, as opposed to

155 Th, which occurs only in the insoluble 4+ valence state. Another study, using Mo content in 156 organic-rich sulfidic shales as a proxy for ocean redox state (Scott et al. 2008), found that Mo 157 content in shales increased at ca. $2.15 \mathrm{Ga}$, and again, more strongly during the Ediacaran Period 158 (ca. $580 \mathrm{Ma})$.

159 McMillan et al. (2010) have described a possibly related trend in mineral chemistry in a study 160 of several dozen molybdenite $\left(\mathrm{MoS}_{2}\right)$ specimens spanning approximately the past 3 billion years. 161 They find that molybdenite with relatively high Re and $\mathrm{W}$ formed primarily during the past 1 162 billion years - a change perhaps related to the gradually increasing mobility of oxidized $\mathrm{Re}^{7+}$ and $163 \mathrm{~W}^{6+}$ (compared with $\mathrm{Re}^{4+}$ and $\mathrm{W}^{4+}$ ) in near-surface oxygenated waters after the GOE.

165 Mineral Diversity

166 Studies of Earth's increasing mineral diversity through time point to the occurrence of new 167 paragenetic modes, including those related to new tectonic and biological mechanisms. Grew and 168 Hazen $(2009,2010 \mathrm{a}, 2010 \mathrm{~b})$ and Grew et al. (2011) reviewed the distribution through time of the 169 minerals of beryllium and boron (Figure 3), two quintessential lithophile elements with average 170 crustal abundances of 2.1 and 17 ppm, respectively (Rudnick and Gao 2004). The 108 approved 171 mineral species containing essential beryllium include 66 silicates, 28 phosphates and arsenates, 1729 oxides and hydroxides, 4 borates, and one carbonate. Beryllium minerals are found most 173 abundantly and in greatest diversity in granitic pegmatites, alkaline and peralkaline pegmatites, 174 hydrothermal deposits associated with volcanic and shallow-level plutonic rocks, and skarns, 175 whereas non-metasomatic metamorphic occurrences are minor and sedimentary occurrences 176 unknown except for placers. Beryllium is a trace element, and therefore minerals containing 
177 essential Be appear only after extensive differentiation, which explains the relatively late first 178 appearance of $\mathrm{Be}$ minerals in the geologic record. Based on reported finds, the oldest Be 179 minerals are Mesoarchean, when two species formed at the Gravelotte emerald deposit in $2969 \pm$ $18017 \mathrm{Ma}$ granitic pegmatites associated with a greenstone belt in South Africa (Poujol 2001). Ten 181 more species are found in later Meso- and Neoarchean (2860 to $2550 \mathrm{Ma}$ ) granitic pegmatites 182 and granulite-facies rocks of the Pilbara and Yilgarn cratons, Australia, and the Bird River 183 Province, Canada. Two species in peralkaline rocks and a metamorphic occurrence on the 184 Yilgarn craton bring the total of Archean Be minerals to 15. Anatectic pegmatites in the 185 ultrahigh-temperature Napier complex, Antarctica, introduce three more species in the earliest 186 Paleoproterozoic, the last to appear before a burst of 28 new species towards the close of the 187 Paleoproterozoic ( 1850-1715 Ma) in both pegmatites (e.g., Norrö, Sweden; Tysfjord, Norway; 188 Tiptop, South Dakota; Red Ace, Wisconsin) and complex skarn deposits of the Långban type in 189 Sweden. From about $1700 \mathrm{Ma}$ to $<1 \mathrm{Ma}$, the number of new Be minerals increased relatively 190 steadily, with a pulse of 14 new species at 1160 Ma (Ilímaussaq peralkaline complex, 191 Greenland). All of the "principal" episodes of Be mineralization cited by Barton and Young 192 (2002) occurred after 1600 Ma. Barton and Young (2002) cautioned that most Be deposits are 193 concentrated at shallow levels in the Earth's crust, and thus older occurrences could have been 194 lost to erosion. Conversely, there are some minerals that formed only once or a few times in the 195 course of Earth's history and have not been reported from other areas, e.g., joesmithite and 196 harstigite from the Långban-type deposits in Sweden.

197 The 241 valid and 22 prospective mineral species containing essential boron include one 198 nitride, four fluorides, and 258 oxygen compounds (borates) of which 129 contain only $B \Phi_{3}$ 199 triangles and/or $\mathrm{B}_{4}$ tetrahedra, where $\Phi=\mathrm{O}, \mathrm{OH}$, and 129 contain additional oxyanionic 
200

201

202

203

204

205

206

207

208

209

210

211

212

213

214

215

216

217

218

219

220

221

222

complexes of $\mathrm{Be}, \mathrm{C}, \mathrm{Si}, \mathrm{P}, \mathrm{S}$, or As. Volcanic and sedimentary processes, together with regional metamorphism and overall greater crustal abundance, concentrated boron sufficiently for B minerals to appear earlier in the geologic record than beryllium minerals. The tourmaline species dravite and schorl from the Isua greenstone belt, Greenland (3800 Ma) are the oldest B minerals reported, but earlier formation of B minerals, including evaporitic phases, cannot be excluded, an issue having implications for stabilization of prebiotic organic compounds (Grew et al. 2011). The next oldest minerals to be reported are bonaccordite and two more tourmalines (foitite and magnesio-foitite) in the Barberton greenstone belt, South Africa (3230 Ma) and a Cr-tourmaline in the Singhbhum craton, India (3100 Ma). Highly differentiated 2520-2670 Ma granitic pegmatites and their exocontacts, 2680-2700 Ma hydrothermal activity associated with gold deposits, and ca. 2800 Ma metamorphic rocks of Fiskenæsset, Greenland brought the total to 20 species in the Archean. The borate deposits in Liaoning and Jilin provinces, China with ca. 2050 Ma metamorphism; Mn skarns in the ca. 1825 Ma Långban-type deposits, Sweden; ca. $1950 \mathrm{Ma}$ skarns in the Tayozhnoye deposit, Russia; and ca. 2000 Ma granitic pegmatites and granulitefacies metamorphic rocks of the Magondi belt, Zimbabwe contributed 32 new species in the late Paleoproterozoic, whereas $\mathrm{Mn}$ deposits and $\mathrm{Mg}$ skarns were largest contributors to 36 more species in the remainder of the Proterozoic. However, the most species, 175, are reported to first appear in the Phanerozoic, including 37 species in $\mathrm{Mg}$ skarns and 20 in alkaline rocks. Evaporites, fumaroles, and secondary minerals in extreme desert environments contributed another 82 species. However, these ephemeral B minerals could have also formed much earlier and, with rare exception, failed to survive later geologic events (Grew et al. 2011). The only borate reported from a Precambrian evaporite is chambersite $\left(\mathrm{Mn}_{3} \mathrm{~B}_{7} \mathrm{O}_{13} \mathrm{Cl}\right)$ associated with algal dolostone in the 1500 Ma Gaoyuzhuang Formation, China (Fan et al. 1999; Shi et al. 2008). 
223 However, B isotopes are consistent with an evaporitic precursor to 2400-2100 Ma metamorphic

224 borates in the Liaoning and Jilin provinces, China (e.g., Peng and Palmer 2002). Relict casts and

225 B isotopes are cited as evidence for an evaporite precursor to the Paleoarchean Barberton 226 tourmaline-rich rocks (Byerly and Palmer 1991), implying a much greater diversity of borate 227 minerals as early as $3400 \mathrm{Ma}$.

228 We conclude that the geologic record provides an incomplete picture of B mineral evolution, 229 much less so than for Be mineral evolution. As in the case of Be minerals, some B minerals are 230 reported from only one or just a few localities; others, notably evaporitic borates, likely were 231 removed from the geological record through erosion and alteration processes. Nonetheless, 232 despite these caveats, we suggest that the overall increasing diversity of both $\mathrm{Be}$ and $\mathrm{B}$ minerals, 233 together with increasing compositional diversity of solid solutions as exemplified by tourmaline234 group minerals, could have resulted from increasing diversity in geologic environments and from 235 mixing of geologic materials as Earth's crust was recycled by tectonic processes. However, 236 uncertainties regarding the distribution and survivability of mineral species underscore the need 237 for normalized data sets capable of distinguishing between increasing mineral diversity through 238 time and decreasing geological loss towards the present.

\section{Relative Abundances of Minerals}

241 Changes with time in the relative abundances of minerals are of prime importance in 242 understanding the evolution of Earth's near-surface environments. Economic geologists have 243 long approached the study of ore deposits by considering the evolution of distinctive mineral 244 associations and classes of mineral deposits (e.g., Nash et al. 1981; Bekker et al. 2010; Farquhar 245 et al. 2010; Goldfarb et al. 2010; Leach et al. 2010). 
246

247

248

249

250

251

252

253

254

255

256

257

258

259

260

261

262

263

264

265

266

267

268

Special attention has also been focused on changes in clay mineralogy, both in absolute and relative terms (Kennedy et al. 2006; Elmore 2009; Tosca et al. 2010). Of note is the massive compilation of Ronov and colleagues (1990), who documented relative clay mineral abundances from approximately 10,000 dated shale samples collected across the Russian Platform - a remarkably large, yet potentially idiosyncratic data set representing the past 1.3 billion years. Sverjensky et al. (2010) demonstrate that these data, which reveal dramatic fluctuations in the relative proportions of kaolinite, chlorite, montmorillonite, and illite, correlate with variations in atmospheric $\mathrm{O}_{2}$ and $\mathrm{CO}_{2}$, as well as with the rise of deep-rooted vascular plants after $400 \mathrm{Ma}$ and the appearance of associated ectomycorrhizal fungi (symbiotic root-associated fungi with hyphae that penetrate the soil) at $200 \mathrm{Ma}$ (Taylor et al. 2009; see Figure 4).

Taken together, these investigations of changing mineral characteristics through time isotope and elemental ratios, species diversity and distribution, associated minerals, and relative abundances - are compelling arguments that far-reaching discoveries can emerge from such an approach. However, a significant impediment to such contributions is the lack of a comprehensive database that provides age information for mineral localities.

\section{A Mineral Evolution Database}

Mineral evolution studies involve correlating mineralogical variables with time and evolving geologic setting. Extensive tabulations of mineral species and localities (notably http://mindat.org) have proven critical in this effort. However, the principal impediment to advancing studies of mineral evolution is the lack of a comprehensive database that links such mineral species and locality information with ages and geologic context. Much of the necessary geochronological data exist in the literature, but in widely scattered primary sources. 
269 Consequently, documenting the age distribution of a single mineral species may require locating 270 ages of several thousand localities in dozens of countries.

\section{Database Development}

273 To advance this effort we have initiated development of a Mineral Evolution Database that 274 will link to existing mineral species and locality data in the comprehensive mindat.org database. 275 This effort is proceeding on two fronts. First, we are beginning a systematic survey of the 276 primary literature to compile all mineral localities with known ages and their geologic settings. 277 This massive undertaking requires the compilation of data on approximately 100,000 mineral 278 localities. However, such database construction will only have to be done once to provide the 279 essential foundation for future mineral evolution studies.

280 This large-scale effort finds an illustrative analog in the Paleobiology Database 281 (http://paleodb.org/cgi-bin/bridge.pl), an international, community-based project to make fossil 282 occurrence data available to all paleontologists. To date, data have been entered for more than 283170,000 taxa and nearly 100,000 collections. As discussed below, this large and growing 284 database not only enables paleontologists to track taxa and assemblages through time (and across 285 environments), but also to normalize sampling in ways that reduce the distorting effects of 286 collection bias (e.g., Alroy et al., 2008; Kiessling et al., 2010; Peters and Heim 2010; Alroy 287 2010).

288 Mindat.org has been running online since October 2000 and is now the largest online database 289 of mineralogical information. The core purpose of mindat.org is to record information about 290 mineral localities worldwide, to list the reported and verified mineral species at these localities, 291 and, where possible, to provide photographs of these localities and their mineral specimens. 292 There are currently over 20,000 registered users on mindat.org, of whom several hundred active 
293

294

295

296

297

298

299

300

301

302

303

304

305

306

307

308

309

310

311

312

313

314 inclusion of new localities not currently in the system. community to question and validate new postings.

contributors submit data and photographs for the project. A management team of approximately 25 members helps to verify new submissions, and a discussion forum allows the wider

The mindat.org website is based on the open source PHP and MySQL systems, using custom software developed primarily by Jolyon Ralph. This software will be updated to allow age information to be entered for use in this mineral evolution project. An advantage of employing the Mindat platform is that data can be exported easily to and from other mineral databases, such as GEOROC (http://georoc.mpch-mainz.gwdg.de/georoc) and PetDB (http://www.petdb.org).

Currently the mindat.org system allows mineral occurrence information to be recorded for each known locality. This capability will be edited to allow those with appropriate access permissions to add information about the age range for each mineral species that has been dated from a particular deposit. This project will thus require those who wish to contribute data to be validated and to have an extra level of access clearance granted to their mindat.org login account. This clearance will allow them to edit and update information on mineral ages.

Special care will be required in identifying the ages of minerals, as opposed to the ages of their host formations. The richness of many mineral localities is a consequence of multiple stages of alteration, which make dating of individual phases difficult. Changes to mindat.org will thus allow managers of the site and administrators of this project to review and, if necessary, modify age information. The site will show who made the changes, what those changes were, and when they were made. All changes will include a valid bibliographic reference for the source of the data. Additions and changes will include both edits to existing mindat.org localities and the 
317 A second parallel effort is development of a software package that will permit flexible data 318 mining of mineral occurrences versus age data. A set of search options will allow users to 319 identify the distribution of occurrences of each mineral species through time, including the 320 earliest and most recent occurrences. It will also be possible to bin these data according to 321 distinctive paragenetic modes or geographical regions. The mindat.org platform is now being 322 modified to facilitate this capability.

323 In addition, software will be created to allow graphical representation of these data, for 324 example by plotting the age distribution of all localities for a given mineral species, or by 325 plotting the ages of first appearance for all minerals in a related group (e.g., minerals of 326 beryllium or sulfate minerals). These searches, which will become more useful over time as more 327 locality age data are entered, will include the ability to show data in both geographical context 328 (on a modern world map) and chronologically. 


\section{UNANSWERED QUESTIONS IN MINERAL EVOLUTION RESEARCH}

Mineral evolution represents an alternative way to frame mineralogy - an approach that complements more traditional presentations of the subject based on solid-state chemistry and physics. Certainly there is considerable pedagogical power in presenting mineralogy in the context of the narrative sweep of Earth history, including nebular evolution, planetary accretion and differentiation, initiation of plate tectonics and continent formation, the evolving composition of the atmosphere, the origins of life, and the evolution of varied biochemical pathways and ecological niches. But does mineral evolution offer anything new as a predictive methodology? Is there anything that might guide mineralogical research in new directions?

The key to development of a long-range mineral evolution program is to examine previously unrecognized temporal trends in mineral properties and distributions by adding the time dimension to mineralogical studies. Here we explore several promising unanswered questions, each of which presents avenues for research that would be facilitated by the proposed mineral evolution database.

\section{Are there temporal trends in the first appearances and cumulative numbers of mineral} species? A database with all localities and their ages for the $>4500$ known mineral species will enable analysis of the diversification of Earth's near-surface mineralogy through time. Studies on the first appearances of minerals of Be and B (Grew and Hazen 2009, 2010a, 2010b) and work in progress on the minerals of $\mathrm{Hg}, \mathrm{Mo}, \mathrm{W}, \mathrm{Cu}, \mathrm{I}$, and $\mathrm{Br}$ point to possible pulses in their origins. However, a comprehensive database of all mineral locality ages is required to distinguish statistically significant increases in the numbers of mineral species from non-uniform temporal distributions of known mineral localities. 
355

One important opportunity is to identify mineral species that are highly sensitive to environmental conditions and, consequently, that reflect aspects of Earth's geochemical, tectonic, and biological evolution. For example, spodumene $\left(\mathrm{LiAlSi}_{2} \mathrm{O}_{6}\right)$ occurs in the $3040 \mathrm{Ma}$ New Consort pegmatites in the Barberton greenstone belt, South Africa (Harris and Robb 1995); these are the oldest known differentiated pegmatites and thus point to early stages of element concentration through partial melting, crystallization, and fluid-rock interactions. Other species such as cassiterite $\left(\mathrm{SnO}_{2}\right)$, pollucite $\left[(\mathrm{Cs}, \mathrm{Na})_{2} \mathrm{Al}_{2} \mathrm{Si}_{4} \mathrm{O}_{12} \cdot\left(\mathrm{H}_{2} \mathrm{O}\right)\right]$, and a number of minerals found in massive sulfide deposits (including rare sulfides and sulfosalts) may also serve as indicators of highly differentiated magmatic and hydrothermal systems, or of multiple recycling of evolved continental crust. High-pressure minerals such as coesite and magnesiodumortierite are largely restricted to crustal rocks subjected to ultrahigh-pressure metamorphism during subduction. Mineral data could thus possibly provide significant constraints on early history of fluid-rock interactions, crustal and mantle dynamics, and the establishment of plate tectonics.

Another potentially revealing research topic is to track detrital minerals and the minerals included in them through time. A wealth of relatively low-grade sedimentary rocks, some as old as $3800 \mathrm{Ma}$, preserve detrital mineral suites that provide forensic data on surface lithologies subjected to erosion. In what may be seen as a precursor study, Taylor and McLennan (1985) used the elemental composition of Archean and Proterozoic shales to infer crustal history. Most previous mineralogical efforts have focused on zircon, but research could be expanded to the whole suite of detrital minerals. For example, Meng (1988) and Meng and Dymek (1987) reported that some metamorphic tourmalines in the $3800 \mathrm{Ma}$ Isua greenstone belt, Greenland have cores inferred to be of detrital origin with compositions plotting in the fields of both metasedimentary and igneous tourmaline (Henry and Guidotti 1985), suggesting the intriguing 
378 possibility of tourmaline-bearing continental crust older than the Isua belt. Detrital almandine 379 garnet and kyanite may also reflect Al-rich lithologies indicative of crustal reworking. Muscovite 380 inclusions in Hadean zircon from Jack Hills, Western Australia are interpreted to suggest that 381 magmas hosting the zircon were derived dominantly from anatexis of metasedimentary rocks, 382 i.e., rocks with precursors deposited in a Hadean ocean (Harrison 2009). The preservation of 383 unaltered detrital pyrite, siderite, and uraninite in Mesoarchean fluvial conglomerates has been 384 cited as evidence for an anoxic surface environment in the Archean (Grandstaff 1980; 385 Rasmussen and Buick 1999; Frimmel 2005; Sverjensky and Lee 2010). Studies that compare the 386 first appearance of mineral phases on different cratons represent yet another opportunity to 387 understand Earth's dynamic history.

388 Systematic surveys of the cumulative numbers of mineral species can reveal if there were 389 pulses of mineral formation, waxing and waning of mineral-forming processes, or even episodes 390 of "mineral extinction." As noted above, paleontological surveys of the number and distribution 391 of fossil species, properly corrected for the areal distributions and ages of fossiliferous 392 formations, have revealed dramatic pulses of biodiversification as well as mass extinctions 393 (Sepkoski 1997; Bambach et al. 2004; Alroy et al. 2008; Alroy 2010). Similar statistical 394 treatments of mineral diversity through time hold the promise of revealing analogous patterns in 395 Earth's mineral evolution. Note, however, that unlike the irreversible extinction of biological 396 species, mineral species that disappear from the rock record in one formation commonly 397 reappear elsewhere as old paragentic conditions are repeated or new paragenetic modes come 398 into play.

399 An important task in this regard is to conduct a survey of the number and areal extent of 400 mineral localities through time in order to document the absolute number or percentage of 
401 localities versus time. Any claims of mineral diversification or extinction events must be scaled

402 to such locality/age statistics, as raw occurrence values will reflect, at least in part, the mapped 403 availability of rocks of differing age and geologic setting. For example, geochronologic studies 404 of zircon reveal a general lack of ages between 2.45 and $2.22 \mathrm{Ga}$, bracketing the time of three 405 major Paleoproterozoic glacial events (Bekker et al. 2005; Condie and Aster 2009). Such gaps in 406 the rock record must be factored into any analysis of mineral diversity through time.

407

2. What do changing mineral assemblages through time reveal about changes in near-surface

409

410

411

412

413

414

415

416

417

418

419

420

421

422 stranded water bodies from which they precipitated. For example, jarosite

$423\left[\left(\mathrm{~K}, \mathrm{Na}, \mathrm{H}_{3} \mathrm{O}, X^{+1}\right) \mathrm{Fe}^{3+}{ }_{3}(\mathrm{OH})_{6}\left(\mathrm{SO}_{4}\right)_{2}\right]$, a family of hydrous iron sulfate minerals, indicates acidity at 
425 Mars may help to illuminate the surface history of that planet (Squyres et al., 2004). Clay 426 minerals are also important in documenting evolution of Earth's near-surface environments 427 (Tosca et al. 2009; Elmore 2009; Sverjensky et al. 2010), including changes in ocean and 428 atmospheric composition, the geochemistry of near-surface aqueous fluids involved in diagenesis 429 and low-grade metamorphism, and the rise of terrestrial biota.

430 Other mineral indicators might have the potential to confirm and constrain the proposed 431 pulses of oxidation in the Neoarchean Era, to provide evidence for the emergence of new modes 432 in continental weathering in the Paleozoic Era, or to track the oxidation state of near-surface 433 aqueous fluids involved in rock alteration and ore formation. A first step might be to arrange 434 mineral species and assemblages according to the minimum $\log \mathrm{fO}_{2}$ required for their formation 435 at plausible near-surface conditions, and then relate those minima with first appearances in the 436 geological record. For example, minerals stable at $\log p \mathrm{O}_{2} \sim-72$ (the hematite-magnetite buffer at 437 standard temperature and pressure) are likely to have been found at or near Earth's surface since 438 the Hadean Eon, whereas minerals containing $\mathrm{Mo}^{6+}, \mathrm{U}^{6+}, \mathrm{Hg}^{2+}, \mathrm{Cu}^{2+}$ and $\mathrm{Mn}^{4+}$ likely appeared 439 later in Earth history at times of higher $\mathrm{pO}_{2}$. Furthermore, if distinctive lithological and textural 440 characteristics offer hints at the depth of emplacement (e.g., the average grain size of a granite), 441 then it might be possible to estimate temporal changes in the oxygen fugacity of near-surface 442 fluids as a function of depth. Much of the necessary geochemical and mineralogical data to 443 constrain models of Earth's near-surface redox history already exist, but these data need to be 444 compiled and systematized in a chronological scheme.

445 Ratios of trace and minor elements and isotopes, especially of redox-sensitive elements, 446 represent an important opportunity for further research. Temporal studies of variations of $\mathrm{Th} / \mathrm{U}$ 447 in black shales (Partin et al. 2010) and Re/Mo in molybdenite (McMillan et al. 2010) over 3 
448 billion years of Earth history demonstrate that elemental ratios can prove to be sensitive 449 indicators of changes in Earth's near-surface environment related to geochemical and 450 biochemical evolution. The isotopic compositions of $\mathrm{Fe}$ and $\mathrm{Mo}$ in sedimentary rocks also 451 provide tools for reconstructing the redox history of seawater (e.g., Rouxel et al. 2005; Anbar 452 and Rouxel 2007; Dahl et al. 2010). Several common minerals and mineral groups, including 453 biopyriboles (i.e., amphiboles, pyroxenes, and micas), garnet, spinel, chlorite, and tourmaline, 454 possess crystal structures that can accommodate dozens of different chemical elements. 455 Systematic investigation of minor and trace elements in these minerals through time could reveal 456 trends that reflect the emergence of new modes of fluid-rock interaction, changes in ocean and 457 atmospheric chemistry, and the influences of living systems.

458 Such investigations will be complicated by the multiple paragenetic modes that are 459 responsible for many mineral species. Such variables can be minimized by focusing on one 460 specific lithology, for example amphibole and mica from fine-grained (i.e., shallow 461 emplacement) granites, through time.

464 lists reveal distinctive environmental characteristics of those periods? As we obtain age 465 information for a significant fraction of all known mineral localities, it would be instructive to 466 compare the mineral diversity through the different eras of Earth history. For example, what are 467 implications of the dozen or so known Hadean mineral species preserved as inclusions in ancient 468 zircons, and do those minerals possess distinctive chemical or isotopic characteristics? Do 469 minerals reflect the biological innovations of the Archean Eon's four Eras (Eoarchean, 3.85-3.6 $470 \mathrm{Ga}$; Paleoarchean, 3.6-3.2 Ga; Mesoarchean, 3.2-2.8 Ga; and Neoarchean, 2.8-2.5 Ga) - a time 471 when life arose and metabolic processes such as nitrogen fixation and photosynthesis evolved? 
472 Similarly, how is the rise of atmospheric oxygen in the Paleoproterozoic Era (2.5-1.6 Ga)

473 reflected in Earth's near-surface mineral diversity? More recently, is the rise of land plants or the

474 late Mesozoic expansion of flowering plants reflected in changing mineralogy?

475 A closely related opportunity lies in documenting what might be termed the "half-life" of 476 mineral species - the average near-surface residence time for minerals in environments subject to 477 erosion, weathering, or other destructive alteration processes. For example, some zircon crystals 478 have survived from at least $4.4 \mathrm{Ga}$, in sharp contrast to evaporite or clay minerals, which are 479 more easily altered, eroded, or otherwise removed from the geological record. Similarly, 480 distinctive minerals associated with serpentinization zones of ocean basalts, or ultra-deep 481 metamorphic zones with high-pressure minerals (e.g., jadeite and coesite), are unlikely to survive 482 much longer than $100 \mathrm{Ma}$ in the dynamic environments associated with plate tectonic processes.

483 Clay minerals present a particularly intriguing and challenging case of mineral survivability. 484 Reports of clay minerals are sparse for rocks older than the Late Archean (e.g., Tosca et al. 485 2010). Does the paucity of older clay minerals primarily reflect their lack of durability (i.e., an 486 inherently short mineralogical half-life) or rather was there also a significantly reduced clay 487 mineral production prior to $2.5 \mathrm{Ga}$ ? Are clay minerals in older rocks original, or were they 488 formed more recently by alteration? Why are ancient clay minerals apparently preserved so well 489 on Mars (Ehlmann et al. 2008), at least compared with the terrestrial environment? In the 490 absence of plate tectonic activity, can clay minerals survive for eons in near-surface 491 environments?

492 In considering the complete inventory of minerals from a given geologic age, it is also 493 intriguing to consider the distribution of trace and minor elements. Prior to the first minerals of 494 Be and B, where did these elements reside? Were they present as dispersed trace elements in 
495 other phases, either in solid solution or in defects? Did they concentrate along grain boundaries, 496 and if so in what form? Are there as yet unrecognized nano-phases? These questions, which 497 could be pursued for example through the nanoscale study of chondrites, are tied closely to 498 traditional concerns of crystal chemistry and the first appearances of varied cation polyhedral 499 and other structural motifs of the mineral kingdom.

500

4. For a given mineral species, what is the age distribution of all known samples; were there 502 periods of increased or reduced rates of mineral formation? It is possible that geochemical, 503 tectonic, or biological events may be manifested in the increased production or suppression of 504 certain key mineral species. A comprehensive survey of all known occurrences of a species 505 through time might thus reveal pulses or gaps. For example, a plot of the approximately 4000 506 known localities of molybdenite versus time, especially if coupled with trace and minor element 507 data and correlated with paragenetic mode, might reveal details of near-surface oxygenation, 508 bioavailability of Mo, the initiation of nitrogen fixation by the Mo-bearing nitrogenase enzyme, 509 and other key events. Furthermore, regional variations in these data might reveal otherwise 510 hidden aspects of paleogeography and tectonic history.

5. What can we learn from changes in crystal morphology through time? The crystal habits of 513 minerals can be strongly influenced by environmental factors, including temperature, pressure, 514 composition of aqueous solutions, and biological activities (Babel 1990; Cody and Cody 1991; 515 Orme et al. 2001; Pope et al. 2000). Calcite $\left(\mathrm{CaCO}_{3}\right)$, for example, is known to occur in dozens 516 of distinct crystal forms - variations that may reveal much about environmental conditions (Teng 517 and Dove 1997; Teng et al. 1998, 2000). Many different organisms precipitate calcite or 518 aragonite in tests and shells (e.g., Stanley and Hardie 1998; Knoll 2003), and still others facilitate 
519 or inhibit $\mathrm{CaCO}_{3}$ nucleation and growth due to the chemical properties of their metabolic

520 products or the physicochemical properties of organic exudates (Pentacost 2005). Systematic

521 surveys of calcite crystal morphology, therefore, might reveal previously unrecognized trends in 522 environmental conditions, including ocean chemistry, hydrothermal systems, and biological 523 innovations.

6. Can minerals provide unambiguous biosignatures (or “abiosignatures”) in our search for 526 life on other worlds? Hazen et al. (2008) concluded that approximately two-thirds of known 527 mineral species on Earth are the indirect consequence of biology, mostly as a consequence of the 528 GOE. If so, then many mineral species may provide an unambiguous signature of a living world. 529 Minerals from the oldest rocks may help to constrain which minerals were involved in the origin 530 of life (Papineau 2010) and prove to be robust and easily detected in the search for 531 extraterrestrial life. That said, we must be cautious, as the expanded repertoire of minerals 532 actually reflects the availability of oxygen, not minerals synthesized solely or even principally by 533 organisms. On Mars the presence of oxides and sulfides reflects redox conditions at and near the 534 planetary surface, whether or not biology influenced those conditions.

535 Biominerals represent another important topic for further research. Which mineral species are 536 produced exclusively by life? Similarly, are some mineral varieties, including those with 537 distinctive compositions (e.g., Th-depleted uraninite) or morphologies (e.g., nano-uraninite), 538 unambiguously formed by biological processes? A fuller understanding of the dependence of 539 mineral diversity on biology is thus a key objective of mineral evolution studies.

541 These unanswered questions in mineral evolution outline a multi-decade program and 542 represent great opportunities for the mineralogical community. 


2

\section{CONCLUSIONS}

What does mineral evolution have to offer that is new? Plots of the diversity of mineral species through time have proven to be an important first step, as they appear to reveal pulses of mineral formation (and possible "extinction") that point to important changes in Earth's nearsurface environment. However, a comprehensive data base that records ages and geologic setting for all known mineral localities will allow much more varied and subtle questions to be addressed. For example, the significance of mass-independent $\mathrm{S}$ isotope effects was only realized after several dozens of $\mathrm{S}$ isotope analyses were plotted versus time (Farquhar et al. 2000), whereas the observation of subtleties in the zircon $\delta^{18} \mathrm{O}$ record required more than 1000 data points (Valley et al. 2005). With access to a comprehensive Mineral Evolution Database and flexible data mining procedures, numerous other questions of this kind could be posed. Thus, the Mineral Evolution Database could lead to original research studies that are difficult to undertake in any other way.

It is too soon to predict what will be found in such a systematic survey of Earth's mineralogy through time. However, we can be confident that new and as yet unsuspected mineralogical markers for such key events as the initiation of plate tectonics, the formation of continents, the origins of life, the global rise of atmospheric oxygen, the greening of the terrestrial environment, and numerous other biological innovations are awaiting discovery. 


\section{ACKNOWLEDGMENTS}

569 We are grateful to Russell Hemley and the Carnegie Institution for Science for a generous 570 grant to support initial development of the Mineral Evolution Database. We thank Claude 571 Herzberg and an anonymous reviewer for constructive comments. This work was supported in 572 part by the NASA Astrobiology Institute. Additional support for D.A. Sverjensky and R.M. 573 Hazen was provided by a NSF-NASA Collaborative Research Grant to the Johns Hopkins

574 University and the Carnegie Institution for Science. D.A. Sverjensky also acknowledges support 575 from DOE Grant DE-FG02-96ER-14616.

576 


\section{REFERENCES CITED}

578

579 Alroy, J. (2010) The shifting balance of diversity among major animal groups. Science, 329, 11915801194.

581 Alroy, J., Aberhan, M., Bottjer, D.J., Foote, M., Fürsich, F.T., Harries, P.J., Hendy, A.J.W., 582 Holland, S.M., Ivany, L.C., Kiessling, W., Kosnik, M.A., Marshall, C.R., McGowan, A.J., 583 Miller, A.I., Olszewski, T.D., Patzkowsky, M.E., Peters, S.E., Villier, L., Wagner, P.J., Bonuso, 584 N., Borkow, P.S., Brenneis, B., Clapham, M.E., Fall, L.M., Ferguson, C.A., Hanson, V.L., Krug, 585 A.Z., Layou, K.M. Leckey, E.H., Nürnberg, S., Powers, C.M., Sessa, J.A., Simpson, C., 586 Tomasovych, A., and Visaggi, C.C. (2008) Phanerozoic trends in the global diversity of marine 587 invertebrates. Science, 321, 97-100.

588 Anbar, A.D. and Rouxel, O. (2007) Metal stable isotopes in paleoceanography. Annual Review of 589 Earth and Planetary Sciences, 35, 717-746.

590 Anbar, A.D., Duan, Y., Lyons, T.W., Arnold, G.L., Kendall, B., Creaser, R.A., Kaufman, A.J., 591 Gordon, G.W., Scott, C., Garvin, J., and Buick, R. (2007) A whiff of oxygen before the Great 592 Oxidation Event? Nature, 317, 1903-1906.

593 Babel, M. (1990) Crystallography and genesis of the giant intergrowths of gypsum from the 594 Miocene evaporites of Poland. American Mineralogist, 44, 103-135.

595 Bambach, R.K., Knoll, A.H., and Wang, S.C. (2004) Origination, extinction, and mass depletions of 596 marine diversity. Paleobiology, 30, 522-542.

597 Bao, H., Rumble III, D., and Lowe, D.R. (2007) The five stable isotope compositions of Fig Tree 598 barite: Implication on sulfur cycle in ca. 3.2 Ga oceans. Geochimica et Cosmochimica Acta, 71, $599 \quad 4868-4879$.

600 Barton, M.D. and Young, S. (2002) Non-pegmatitic deposits of beryllium: Mineralogy, geology, 
601 phase equilibria and origin. In E.S. Grew, Ed., Beryllium: Mineralogy, Petrology and 602 Geochemistry, pp. 591-691. Reviews in Mineralogy and Geochemistry, 50, Mineralogical 603 Society of America and the Geochemical Society, Washington, D.C.

604 Bekker, A., Holland, H.D., Wang, P.-L., Rumble III, D., Stein, H.J., Hannah, J.L., Coetzee, L.L., 605 and Beukes, N.J. (2004) Dating the rise of atmospheric oxygen. Nature, 427, 117-120.

606 Bekker, A., Kaufman, A.J., Karhu, J.A., and Eriksson, K.A. (2005) Evidence for Paleoproterozoic 607 cap carbonates in North America. Precambrian Research, 137, 167-206.

608 Bekker, A., and Kaufman, A.J. (2007) Oxidative forcing of global climate change: a 609 biogeochemical record across the oldest Paleoproterozoic ice age in North America. Earth and 610 Planetary Science Letters, 258, 486-499.

611 Bekker, A., Barley, M.E., Fiorentini, M.L., Rouxel, O.J., Rumble, D., and Beresford, S.W. (2009) 612 Atmospheric sulfur in Archean komatiite-hosted nickel deposits. Science, 326, 1086-1089.

613 Bekker, A., Slack, J.F., Planavsky, N., Krapež, B., Hofmann, A., Konhauser, K.O., and Rouxel, O.J. 614 (2010) Iron formation: The sedimentary product of a complex interplay among mantle, tectonic, 615 oceanic, and biospheric processes. Economic Geology, 105, 467-508.

616 Berner, R.A. (2006) GEOCARBSULF: A combined model for Phanerozoic atmospheric $\mathrm{O}_{2}$ and $617 \mathrm{CO}_{2}$. Geochimica et Cosmochimica Acta, 70, 5653-5664.

618 Byerly, G.R. and Palmer, M.R. (1991) Tourmaline mineralization in the Barberton greenstone belt, 619 South Africa: early Archean metasomatism by evaporite-derived boron. Contributions to 620 Mineralogy and Petrology, 107, 387-402.

621 Canfield, D.E., Habicht, K.S., and Thamdrup, B. (2000) The Archean sulfur cycle and the early 622 history of atmospheric oxygen. Science, 288, 658-661.

623 Canfield, D.E., Poulton, S.W., Knoll, A.H., Narbonne, G.M., Ross, G., Goldberg, T., and Strauss, 
624 H., (2008) Ferruginous conditions dominated later Neoproterozoic deep-water chemistry.

625 Science, 321, 949-952.

626 Cates, N.L., and Mojzsis, S.J. (2006) Chemical and isotopic evidence for widespread Eoarchean

627 metasedimentary enclaves in southern West Greenland. Geochimica et Cosmochimica Acta, 70,

$628 \quad 4229-4257$.

629 Cavosie, A.J., Valley, J.W., and Wilde, S.A. (2007) The oldest terrestrial mineral record: A review 630 of 4400 to 4000 Ma detrital zircons from the Jack Hills, Western Australia. In: M.J. van 631 Kranendonk, R.H. Smithies, and V.C. Bennett (eds). Earth's Oldest Rocks. Developments in 632 Precambrian Geology, 15, 91-111.

633 Cody, A.M. and Cody, R.D. (1991) Chiral habit modification of gypsum from epitaxiallike 634 adsorption of stereospecific growth inhibitors. Journal of Crystal Growth, 113, 508-519.

635 Condie, K.C. and Aster, R.C. (2009) Zircon age episodicity and growth of continental crust. EOS 636 Transactions of the American Geophysical Union, 90(41), 364.

637 Dahl, T.W., Hammarlund, E., Gill, B.C., Knoll, A.H., Anbar, A.D., Gordon, G.W., Bond, D.P.G., 638 Schovsbo, N.H., Nielsen, A.T., and Canfield, D.E. (2010) Devonian rise in atmospheric oxygen 639 correlated to the radiations of terrestrial plants and large predatory fish. Proceedings of the 640 National Academy of Sciences, USA, in press.

641 Domagal-Goldman, S.D., Kasting, J.F., Johnston, D.T., and Farquhar, J. (2008) Organic haze, 642 glaciations and multiple sulfur isotopes in the Mid-Archean Era. Earth and Planetary Science 643 Letters, 269, 29-40.

644 Ehlmann, B.L., Mustard, J.F., Fassett, C.I., Schon, S.C., Head, J.W. III, Des Marais, D.J., Grant, 645 J.A., and Murchie, S.L. (2008) Clay minerals in delta deposits and organic preservation potential 646 on Mars. Nature Geoscience, 1, 355-358. 
647 Elmore, S. (2009) Clay Mineral Evolution. Masters Thesis, George Mason University, 76 p. 648 Fan, D., Yang, P., Wang, R. (1999) Characteristics and origin of the Middle Proterozoic 649 Dongshuichang chambersite deposit, Jixian, Tianjin, China. Ore Geology Reviews, 15, 15-29. 650 Farquhar, J., Bao, H., and Thiemens, M.H. (2000) Atmospheric influence of Earth's earliest sulfur 651 cycle. Science, 289, 756-758.

652 Farquhar, J., Savarino, I., Airieau, S., and Thiemens, M.H. (2001) Observations of wavelength653 sensitive, mass-independent sulfur isotope effects during $\mathrm{SO}_{2}$ photolysis: Implications for the 654 early atmosphere. Journal of Geophysical Research-Planets, 106, 1-11.

655 Farquhar, J., Wing, B.A., McKeegan, K.D., Harris, J.W., Cartigny, P., and Thiemens, M.H. (2002)

656 Mass-independent sulfur of inclusions in diamond and sulfur recycling on early earth. Science, $657298(5602), 2369-2372$.

658 Farquhar, J., Peters, M., Johnston, D.T., Strauss, H., Masterson, A., Wiechert, U., and Kaufman, 659 A.J. (2007) Isotopic evidence for mesoarchean anoxia and changing atmospheric sulphur 660 chemistry, Nature, 449, 706-709.

661 Farquhar, J., Wu, N.P., Canfield, D.E., and Oduro, H. (2010) Connections between sulfur cycle 662 evolution, sulfur isotopes, sediments, and base metal deposits. Economic Geology, 105, 509-533. 663 Frimmel, H.E. (2005) Archaean atmospheric evolution: evidence from the Witwatersrand gold 664 fields, South Africa. Earth-Science Reviews, 70, 1-46.

665 Goldfarb, R.J., Bradley, D., and Leach, D.L. (2010) (2010) Secular variations in economic geology. 666 Economic Geology, 105, 459-465.

667 Grandstaff, D.E. (1980) Origin of uraniferous conglomerates at Elliot Lake, Canada, and 668 Witwatersrand, South Africa: Implications for oxygen in the Precambrian atmosphere. 669 Precambrian Research, 13, 1-26. 
670 Grew, E. and Hazen, R.M. (2009) Evolution of the minerals of beryllium, a quintessential crustal 671 element [Abstract]. Geological Society of America Abstracts with Programs, 41(7), 99.

672 Grew, E. and Hazen, R.M. (2010a) Evolution of the minerals of beryllium, and comparison with 673 boron mineral evolution [Abstract]. Geological Society of America Abstracts with Programs, $674 \quad 42(5), 199$.

675 Grew, E. and Hazen, R.M. (2010b) Evolution of boron minerals: Has early species diversity been 676 lost from the geological record? [Abstract]. Geological Society of America Abstracts with 677 Programs, 42(5), 92.

678 Grew, E.S., Bada, J.L., and Hazen, R.M. (2011) Borate minerals and origin of the RNA world. 679 Origins of Life and Evolution of Biosphere, 41, in press. DOI 10.1007/s11084-101-9233-y. 680 Guo, Q.J., Strauss, H., Kaufman, A.J., Schroder, S., Gutzmer, J., Wing, B., Baker, M.A., Bekker, 681 A., Jin, Q.S., Kim, S.T., and Farquhar, J. (2009) Reconstructing Earth's surface oxidation across 682 the Archean-Proterozoic transition. Geology, 37, 399-402.

683 Habicht, K.S., Gade, M., Thamdrup, B., Berg, P., and Canfield, D.E. (2002) Calibration of sulfate 684 levels in the Archean ocean. Science, 298, 2372-2374.

685 Halevy, I., Johnston, D.T., and Schrag, D.P. (2010) Explaining the structure of the Archean mass686 independent sulfur isotope record. Science, 329, 204-207.

687 Hardie, L.A. (2003) Secular variations in Precambrian seawater chemistry and the timing of 688 Precambrian aragonite seas and calcitic seas. Geology, 31, 785-788.

689 Harris, P.D. and Robb, L.J. (1995) The nature and structural setting of rare-element pegmatites 690 along the northern flank of the Barberton greenstone belt, South Africa. South African Journal of 691 Geology, 98, 82-94.

692 Harrison, T.M. (2009) The Hadean crust: Evidence from $>4$ Ga zircons. Annual Review of Earth 

and Planetary Sciences, 37, 479-505.

694 Hazen, R.M. and Ferry, J.M. (2010) Mineral evolution: Mineralogy in the fourth dimension. 695 Elements, 6, 9-12.

696 Hazen, R.M., Papineau, D., Bleeker, W., Downs, R.T., Ferry, J.M., McCoy, T.J., Sverjensky, D.A., 697 and Yang, H. (2008) Mineral evolution. American Mineralogist, 93, 1693-1720.

698 Hazen, R.M., Ewing, R.C., and Sverjensky, D.A. (2009) Evolution of uranium and thorium 699 minerals. American Mineralogist, 94, 1293-1311.

700 Henry, D. J. and Guidotti, C.V. (1985) Tourmaline as a petrogenetic indicator mineral: An example 701 from the staurolite-grade metapelites of NW Maine. American Mineralogist, 70, 1-15

702 Hofmann, A., Bekker, A., Rouxel, O., Rumble, D., and Master, S. (2009) Multiple sulfur and iron 703 isotope composition of detrital pyrite in Archaean sedimentary rocks: A new tool for provenance 704 analysis. Earth and Planetary Science Letters, 286, 436-445.

705 Holland, H.D. (2002) Volcanic gases, black smokers, and the Great Oxidation Event. Geochimica et 706 Cosmochimica Acta, 66, 3811-3826.

707 Hoskin, P.W.O. and Schaltegger, U. (2003) The composition of zircon and igneous and 708 metamorphic petrogenesis. In: Hanchar, J.M. and Hoskin, P.W.O. (Eds.), Zircon. Reviews in 709 Mineralogy and Geochemistry, 53, 27-55.

$710 \mathrm{Hu}$, G.X., Rumble, D., and Wang, P.L. (2003) An ultraviolet laser microprobe for the in situ 711 analysis of multisulfur isotopes and its use in measuring Archean sulfur isotope mass712 independent anomalies. Geochimica et Cosmochimica Acta, 67, 3101-3118.

713 Ireland, T.R. and Williams, I.S. (2003) Considerations in zircon geochronology by SIMS. In: 714 Hanchar, J.M., Hoskin, P.W.O. (Eds.), Zircon. Reviews in Mineralogy and Geochemistry, 53, $715 \quad 215-242$. 
716 Johnson, B.F. (2009) Mineral take on a new life. Earth 54, \#1, 14-15.

717 Johnston, D.T., Wing, B.A., Farquhar, J., Kaufman, A.J., Strauss, H., Lyons, T.W., Kah, L.C., and 718 Canfield, D.E. (2005) Active microbial sulfur disproportionation in the Mesoproterozoic. 719 Science, 310, 1477-1479.

720 Johnston, D.T., Poulton, S.W., Fralick, P.W., Wing, B.A., Canfield, D.E., and Farquhar, J. (2006) 721 Evolution of the oceanic sulfur cycle at the end of the Paleoproterozoic. Geochimica et 722 Cosmochimica Acta, 70, 5723-5739.

723 Johnston, D.T., Farquhar, J., Summons, R.E., Shen, Y., Kaufman, A.J., Masterson, A.L., and 724 Canfield, D.E. (2008) Sulfur isotope biogeochemistry of the Proterozoic McArthur Basin. 725 Geochimica et Cosmochimica Acta, 72, 4278-4290.

726 Johnston, D.T., Poulton, S.W., Dehler, C., Porter, S., Husson, J, Canfield, D.E., and Knoll A.H. 727 (2010) An emerging picture of Neoproterozoic ocean chemistry: Insights from the Chuar Group, 728 Grand Canyon, USA. Earth and Planetary Science Letters, 290, 64-73.

729 Kamber, B.S. and Whitehouse, M.J. (2007) Micro-scale sulphur isotope evidence for sulphur 730 cycling in the late Archean shallow ocean. Geobiology, 5, 5-17.

731 Kaufman, A.J., Corsetti, F.A., and Varni, M.A. (2007) The effect of rising atmospheric oxygen on 732 carbon and sulfur isotope anomalies in the Neoproterozoic Johnnie Formation, Death Valley, 733 USA. Chemical Geology, 237, 47-63.

734 Kennedy, M., Droser, M., Mayer, L. M., Pevear, D., and Mrofka, D. (2006) Late Precambrian 735 oxygenation: Inception of the clay mineral factory. Science, 311, 1446-1449.

736 Kiessling, W., Simpson, C., and Foote, M. (2010) Reefs as cradles of evolution and sources of 737 biodiversity in the Phanerozoic. Science, 327, 196-198.

738 Klein, C. (2005) Some Precambrian banded iron-formations (BIFs) from around the world: their 
739 age, geologic setting, mineralogy, metamorphism, geochemistry, and origin. American 740 Mineralogist, 90, 1473-1499.

741 Knoll, A.H. (2003) Biomineralization and evolutionary history. In: Dove, P., J. de Yoreo, and S. 742 Weiner, eds., Biomineralization. Reviews in Mineralogy and Geochemistry, 54, 329-356.

743 Leach, D.L., Bradley, D.C., Huston, D., Pisarevsky, S.A., Taylor, R.D., and Gardoll, S.J. (2010) 744 Sediment-hosted lead-zinc deposits in Earth history. Economic Geology, 105, 593-625.

745 Lyons T.W., Anbar A.D., Severmann S., Scott C., Gill B.C. (2009) Tracking euxinia in the ancient 746 ocean: a multiproxy perspective and Proterozoic case study. Annual Review of Earth and 747 Planetary Sciences, 37, 507-534.

748 McMillan, M., Downs, R.T., Stein, H., Zimmerman, A., Beitscher, B., Sverjensky, D.A., Papineau, 749 D., Armstrong, J., and Hazen, R.M. (2010) Molybdenite mineral evolution: A study of trace 750 elements through time. Geological Society of America Abstracts with Programs, 42 (5), 93.

751 Meng, Y. (1988) Tourmaline from the Isua supracrustal belt, southern West Greenland. Master's 752 thesis, Washington University, Saint Louis, Missouri.

753 Meng, Y. and Dymek, R. F. (1987) Compositional relationships and petrogenetic implications of 754 tourmaline from the 3.8 Ga Isua supracrustal belt, West Greenland. Geological Society of 755 America Abstracts with Programs, 19 (7), 770.

756 Mojzsis, S.J., Coath, C.D., Greenwood, J.P., McKeegan, K.D., and Harrison, T.M. (2003) Mass757 independent isotope effects in Archean (2.5 to $3.8 \mathrm{Ga})$ sedimentary sulfides determined by ion 758 microprobe analysis. Geochimica et Cosmochimica Acta, 67, 1635-1658.

759 Monster, J., Appel, P.W.U., Thode, H.G., Schidlowski, M., Carmichael, C.M., and Bridgwater, D. 760 (1979) Sulfur isotope studies in early Archaean sediments from Isua, West Greenland 761 Implications for the antiquity of bacterial sulfate reduction. Geochimica et Cosmochimica Acta, 
763 Nash, J.T., Granger, H.C., and Adams, S.S. (1981) Geology and concepts of genesis of important 764 types of uranium deposits. Economic Geology, $75^{\text {th }}$ Anniversary Volume, 63-116.

765 Ohmoto, H., Watanabe, Y., Ikemi, H., Poulson, S.R., and Taylor, B.E. (2006) Sulphur isotope 766 evidence for an oxic Archaean atmosphere. Nature, 442, 908-911.

767 Ono, S., Beukes, N.J., Rumble, D., and Fogel, M.L. (2006) Early evolution of atmospheric oxygen 768 from multiple-sulfur and carbon isotope records of the 2.9 Ga Mozaan Group of the Pongola 769 Supergroup, Southern Africa. South African Journal of Geology, 109, 97-108.

770 Ono, S.H., Beukes, N.J., and Rumble, D. (2009) Origin of two distinct multiple-sulfur isotope 771 compositions of pyrite in the 2.5 Ga Klein Naute Formation, Griqualand West Basin, South 772 Africa. Precambrian Research, 169, 48-57.

773 Orme, C.A., Noy, A., Wierzbicki, A., McBride, M.T., Grantham, M., Teng, H.H., Dove, P.M., and 774 DeYoreo, J.J. (2001) Formation of chiral morphologies through selective binding of amino acids 775 to calcite surface steps. Nature, 411, 775-778.

776 Papineau, D. (2010) Mineral environments on the earliest Earth. Elements, 6, 25-30.

777 Papineau, D. and Mojzsis, S.J. (2006) Mass-independent fractionation of sulfur isotopes in sulfides 778 from the pre-3770 Ma Isua Supracrustal Belt, West Greenland. Geobiology, 4, 227-238.

779 Papineau, D., Mojzsis, S.J., Coath, C.D., Karhu, J.A., and McKeegan, K.D. (2005) Multiple sulfur 780 isotopes of sulfides from sediments in the aftermath of Paleoproterozoic glaciations. Geochimica 781 et Cosmochimica Acta, 69, 5033-5060.

782 Papineau, D., Mojzsis, S.J., and Schmitt, A.K. (2007) Multiple sulfur isotopes from 783 Paleoproterozoic Huronian interglacial sediments and the rise of atmospheric oxygen. Earth and 784 Planetary Science Letters, 255, 188-212. 
785 Partin, C., Bekker, A., Scott, C., Gill, B., and Lyons, T. (2010) Uranium in shales as a proxy for the 786 evolution of surficial redox conditions (abstract). GeoCanada 2010.

787 Partridge, M.A., Golding, S.D., Baublys, K.A., and Young, E. (2008) Pyrite paragenesis and 788 multiple sulfur isotope distribution in late Archean and early Paleoproterozoic Hamersley Basin 789 sediments. Earth and Planetary Science Letters, 272, 41-49.

790 Pavlov, A.A. and Kasting, J.F. (2002) Mass-independent fractionation of sulfur isotopes in Archean 791 sediments: Strong evidence for an anoxic Archean atmosphere. Astrobiology, 2(1), 27-41.

792 Peng, Q.-M. and Palmer, M.R. (2002) The Paleoproterozoic Mg and Mg-Fe borate deposits of 793 Liaoning and Jilin Provinces, northeast China. Economic Geology, 97, 93-108.

794 Pentacost, A. (2005) Travertines. Springer-Verlag, Hiedelberg, 445 pp.

795 Perkins, S. (2008) As life evolves, minerals do too. Science News 174, \#12, 10.

796 Peters, S.E. and Heim, N.A. (2010) The geological completeness of paleontological sampling in 797 North America. Paleobiology, 36, 61-79.

798 Philippot, P., Van Zuilen, M., Lepot, K., Thomazo, C., Farquhar, J., and Van Kranendonk, M.J. 799 (2007) Early Archaean microorganisms preferred elemental sulfur, not sulfate. Science, 317, $800 \quad 1534-1537$.

801 Pope, M.C., Grotzinger, J.P., and Schreiber, B.C. (2000) Evaporitic subtidal stromatolites produced 802 by in situ precipitation: Textures, facies associations, and temporal significance. Journal of 803 Sedimentary Research, 70, 1139-1151.

804 Poujol, M. (2001) U-Pb isotopic evidence for episodic granitoid emplacement in the Murchison 805 greenstone belt, South Africa. Journal of African Earth Sciences, 33, 155-163.

806 Rasmussen, B. and Buick, R. (1999) Redox state of the Archean atmosphere: Evidence from detrital 807 minerals in ca. 3250-2750 sandstones from the Pilbara Craton, Australia. Geology, 27, 115-118. 
808 Ronov, A.B., Migdisov, A.A., and Hahne, K. (1990) On the problem of abundance and composition 809 of clays of the sedimentary cover of the Russian Platform. Geokhimiya, 467-482.

810 Rosing, M.T. (2008) On the evolution of minerals. Science, 456, 456-458.

811 Rouxel, O., Bekker, A., and Edwards, K. (2005) Iron isotope constraints on the Archean and 812 Paleoproterozoic ocean redox state. Science, 307, 1088-1091

813 Rudnick, R.L. and Gao, S. (2004) Composition of the continental crust. In R.L. Rudnick, Ed., The 814 Crust, Volume 3 of H.D. Holland and K.K. Turekian, Eds., Treatise on Geochemistry, 1-64. 815 Elsevier-Pergamon, Oxford.

816 Schroeder, S., Bekker, A., Beukes, N.J., Strauss, H., and van Niekerk, H.S. (2008) Rise in seawater 817 sulphate concentration associated with the Paleoproterozoic positive carbon isotope excursion: 818 evidence from sulphate evaporites in the similar to 2.2-2.1 Gyr shallow-marine Lucknow 819 Formation, South Africa. Terra Nova, 20, 108-117.

820 Scott, C., Lyons, T.W., Bekker, A., Shen, Y., Poulton, S.W., Chu, X., and Anbar, A.D. (2008) 821 Tracing the stepwise oxygenation of the Proterozoic ocean. Nature, 452, 456-459.

822 Scott, C., Bekker, A., Reinhard, C.T., Schnetger, B., Krapež, B., Rumble III, D., and Lyons, T.W. 823 (2011) Late Archean euxinic conditions before the rise of atmospheric oxygen. Geology, 39, $824 \quad 119-122$.

825 Sepkoski, J.J. (1997) Biodiversity: Past, present, and future. Journal of Paleontology, 71, 533-539. 826 Shi, X., Zhang, C., Jiang, G., Liu, J., Wang, Y. and Liu, D. (2008) Microbial mats in the 827 Mesoproterozoic carbonates of the North China platform and their potential for hydrocarbon 828 generation. Journal of China University of Geosciences, 19, 549-566.

829 Sleep, N.H., Zahnle, K., and Neuhoff, P.S. (2001) Initiation of clement conditions on the earliest 830 Earth (2001) Proceedings of the National Academy of Sciences, 98, 3666-3672. 
831 Squyres, S. and others (2004) In-situ evidence for an ancient aqueous environment on Mars. 832 Science, 306, 1709-1714.

833 Stanley, S.M. and Hardie, L.A. (1998) Secular oscillations in the carbonate mineralogy of reef834 building and sediment-producing organisms driven by tectonically forced shifts in seawater 835 chemistry. Paleogeography Paleoclimatology Paleoecology, 144, 3-19.

836 Sverjensky, D.A., Hazen, R.M., Azzolini, D., Hinnov, L., and Lee, N. (2010) The great oxidation 837 event, mineral diversification, and mineral correlations with atmospheric composition through 838 geologic time. Geological Society of America Abstracts with Programs, 42 (5), 199.

839 Taylor, L.L., Leake, J.R., Quirk, J., Hardy, K., Banwart, S.A., and Beerling, D.J. (2009) Biological 840 weathering and the long-term carbon cycle: Integrating mycorrhizal evolution and function into 841 the current paradigm. Geobiology, 7, 171-191.

842 Taylor, S.R. and McLennan, S.M. (1985) The Continental Crust: Its Composition and Evolution. 843 Blackwell Scientific, Palo Alto CA, 328 p.

844 Teng, H.H. and Dove, P.M. (1997) Surface site-specific interactions of aspartate with calcite during 845 dissolution: Implications for biomineralization. American Mineralogist, 82, 878-887.

846 Teng, H.H., Dove, P.M., Orme, C., and DeYoreo, J.J. (1998) The thermodynamics of calcite 847 growth: A Baseline for understanding biomineral formation. Science, 282, 724-727.

848 Teng, H.H., Dove, P.M., and DeYoreo, J.J. (2000) Kinetics of calcite growth: Analysis of surface 849 processes and relationships to macroscopic rate laws. Geochimica et Cosmochimica Acta, 64, $850 \quad 2255-2266$.

851 Thomassot, E., Cartigny, P., Harris, J.W., Lorand, J.P., Rollion-Bard, C., and Chaussidon, M. 852 (2009) Metasomatic diamond growth: A multi-isotope study (C-13, N-15, S-33, S-34) of 853 sulphide inclusions and their host diamonds from Jwaneng (Botswana). Earth and Planetary 
854 Science Letters, 282, 79-90.

855 Tosca, N.J., Johnston, D.T., Mushegian, A., Rothman, D.H., and Knoll, A.H. (2010) Clay 856 mineralogy, organic carbon burial, and redox evolution in Proterozoic oceans. Geochimica et 857 Cosmochimica Acta, 74, 1579-1592.

858 Trail, D., Mojzsis, S.J., and Harrison, T.M. (2007) Thermal events documented in Hadean zircons 859 by ion microprobe depth profiles. Geochimica et Cosmochimica Acta, 71, 4044-4065.

860 Ueno, Y., Ono, S., Rumble, D., and Maruyama, S. (2008) Quadruple sulfur isotope analysis of ca. 8613.5 Ga Dresser Formation: New evidence for microbial sulfate reduction in the early Archean. 862 Geochimica et Cosmochimica Acta, 72, 5675-5691.

863 Valley, J.W. (2003) Oxygen isotopes in zircon. In: Hanchar, JM and Hoskin, PWO (eds) Zircon. 864 Reviews in Mineralogy and Geochemistry, 53, 343-385.

865 Valley, J.W. (2008) The origin of habitats. Geology, 36, 911-912.

866 Valley, J.W., Peck, W.H., King, E.M., Wilde, S.A. (2002) A cool early Earth. Geology, 30, 351867354.

868 Valley, J.W., Lackey, J.S., Cavosie, A.J., Clechenko, C.C., Spicuzza, M.J., Basei, M.A.S., 869 Bindeman, I.N., Ferreira, V.P., Sial, A.N., King, E.M., Peck, W.H., Sinha, A.K., and Wei, C.S. 870 (2005) 4.4 billion years of crustal maturation: oxygen isotope ratios of magmatic zircon. 871 Contributions to Mineralogy and Petrology, 150, 561-580.

872 Vasconcelos, C. and McKenzie, J.A. (2009) The descent of minerals. Science, 323, 218-219.

873 Whitehouse, M.J., Kamber, B.S., Fedo, C.M., and Lepland, A. (2005) Integrated Pb- and S-isotope 874 investigation of sulphide minerals from the early Archaean of southwest Greenland. Chemical 875 Geology, 222, 112-131.

876 Wu, N.P., Farquhar, J., Strauss, H., Kim, S.T., and Canfield, D.E. (2010) Evaluating the S-isotope 
877 fractionation associated with Phanerozoic pyrite burial. Geochimica et Cosmochimica Acta, 74, $878 \quad 2053-2071$.

879

880

881 


\section{FIGURES AND CAPTIONS}

883 Figure 1. Plot of $\Delta^{33} \mathrm{~S}$ values versus age for sulfide and sulfate minerals. Inset shows $\Delta^{33} \mathrm{~S}$ values 884 versus sample age for evaporite minerals and carbonate-associated sulfate. The disappearance of 885 significant mass independent sulfur isotope fractionation in the past 2.4 billion years has been 886 linked to the rise of a UV-shielding ozone layer during the Great Oxidation Event, and the 887 variation in the $\Delta^{33} \mathrm{~S}$ of oceanic sulfate (inset) is interpreted to reflect changes in the microbial 888 ecology of the oceanic sulfur cycle (data sources include Farquhar et al. 2000, 2002, 2007; Hu et 889 al. 2003; Ono et al. 2006, 2009; Mojzsis et al. 2003; Bekker et al. 2004, 2009; Johnston et al. 890 2005, 2006, 2008; Whitehouse et al. 2005; Ohmoto et al. 2006; Papineau and Mojzsis 2006; 891 Cates and Mojzsis 2006; Papineau et al. 2005, 2007; Bao et al. 2007; Philippot et al. 2007; 892 Kaufman et al. 2007; Kamber and Whitehouse 2007; Ueno et al. 2008; Partridge et al. 2008). 893 (Courtesy of James Farquhar)

894

895 Figure 2. $\delta^{18} \mathrm{O}$ values of zircon grains from 1,200 rocks spanning more than $96 \%$ of Earth history 896 (Valley et al. 2005) reveal variations in $\delta^{18} \mathrm{O}$ values that point to the evolution of both crustal 897 recycling and crust-mantle interactions through time. (Courtesy of John Valley.)

898

899 Figure 3. Plot of the reported oldest occurrences of 107 Be minerals of 108 total (the age for 900 jeffreyite could not be established from the available data) and $263 \mathrm{~B}$ minerals based on 901 literature search (Grew and Hazen unpublished data). The plot is cumulative because each 902 reported new appearance is added to the number of minerals having been reported prior to the 903 age of the appearance. The plot is not meant to indicate the totality of minerals forming in the 
904 Earth's near surface at any given time, including the present; i.e., some minerals formed once or 905 over a limited time interval, and have not formed since. (Courtesy of Edward Grew)

906

907 Figure 4. Ronov et al. (1990) documented relative clay mineral abundances from approximately 90810,000 shale samples collected across the Russian Platform, representing the past 1.3 billion 909 years. Sverjensky et al. (2010) noted that fluctuations in relative clay abundances over the past 910600 million years correlate with variations in atmospheric $\mathrm{O}_{2}$ and $\mathrm{CO}_{2}$. For example, the relative 911 abundance of chlorite in shales tracks values of the level of atmospheric $\mathrm{O}_{2}$ inferred from the 912 GEOCARBSULF model. (Red labels represent abbreviations for geological time intervals.) The 913 deviations from this correlation in the past 200 million years might reflect the rise of mycorrhizal 914 fungi. (Courtesy of Dimitri Sverjensky) 


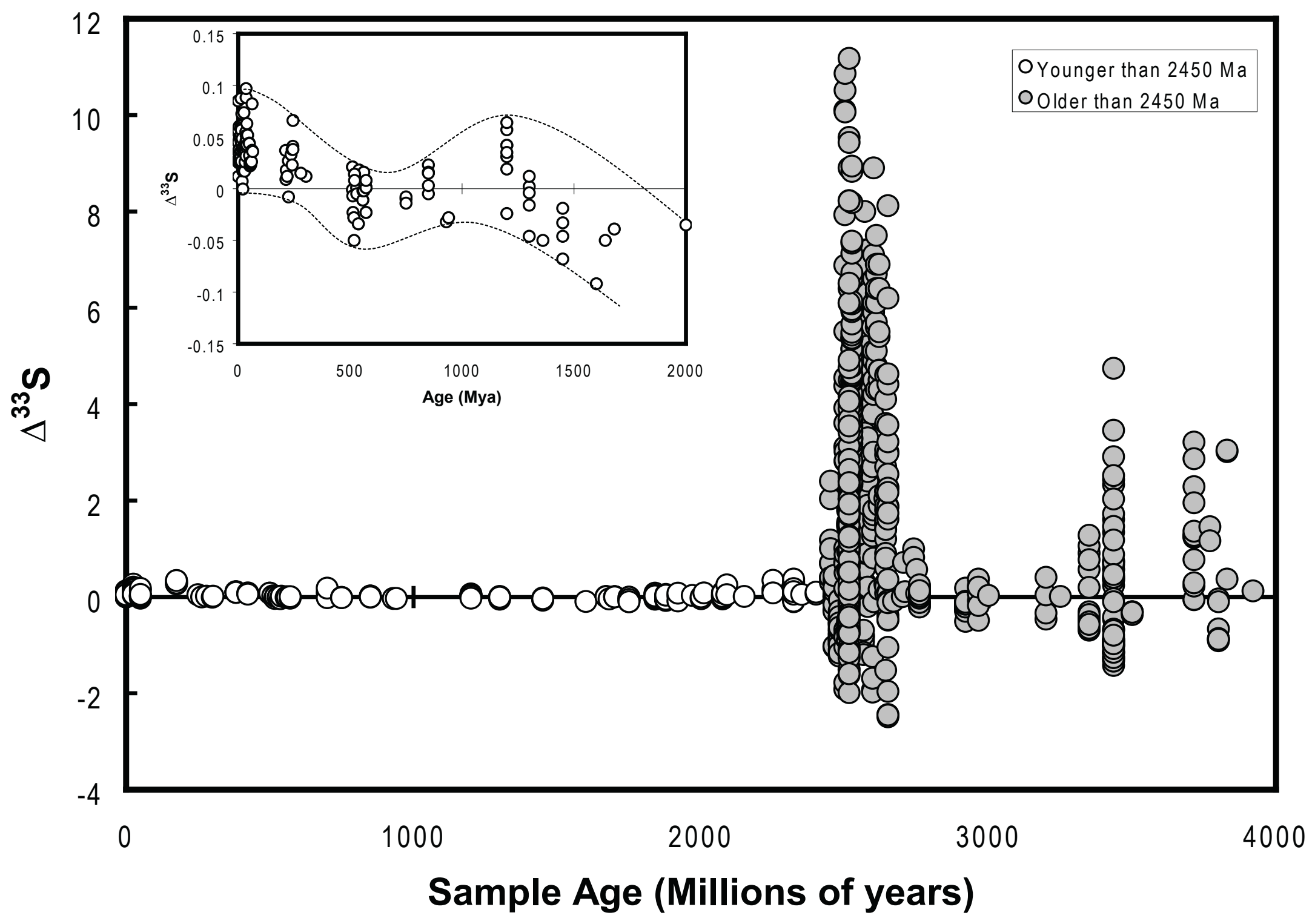




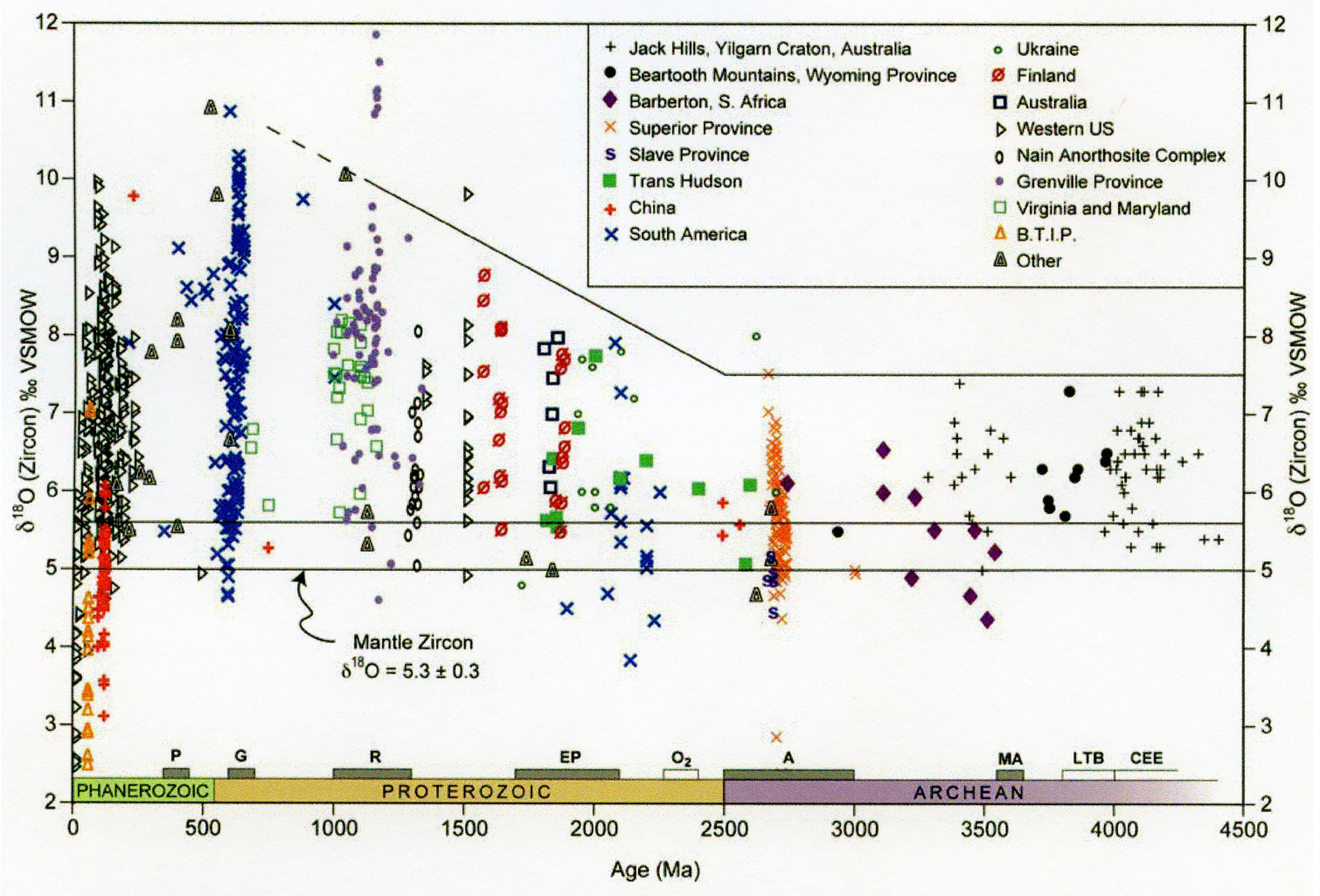




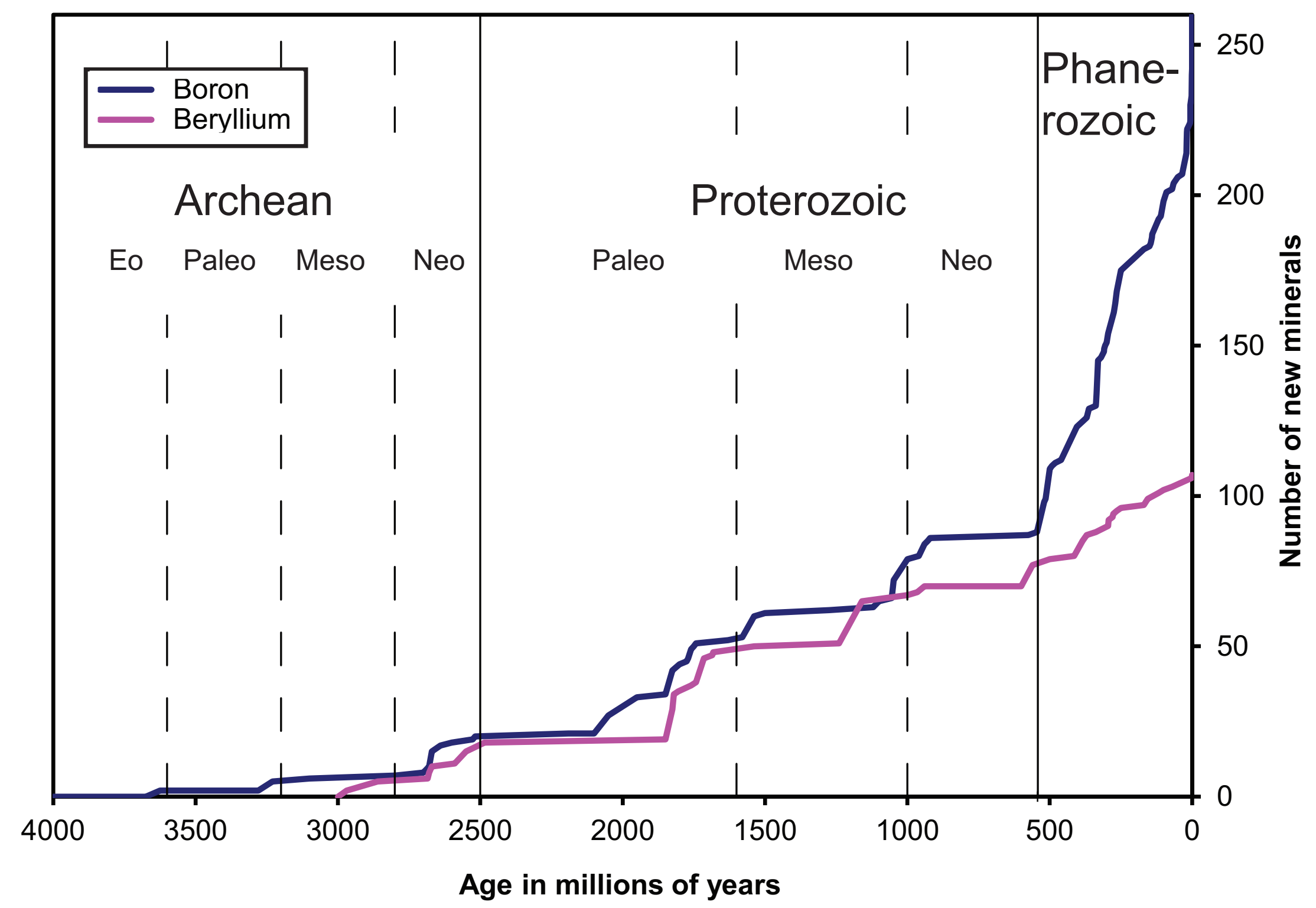




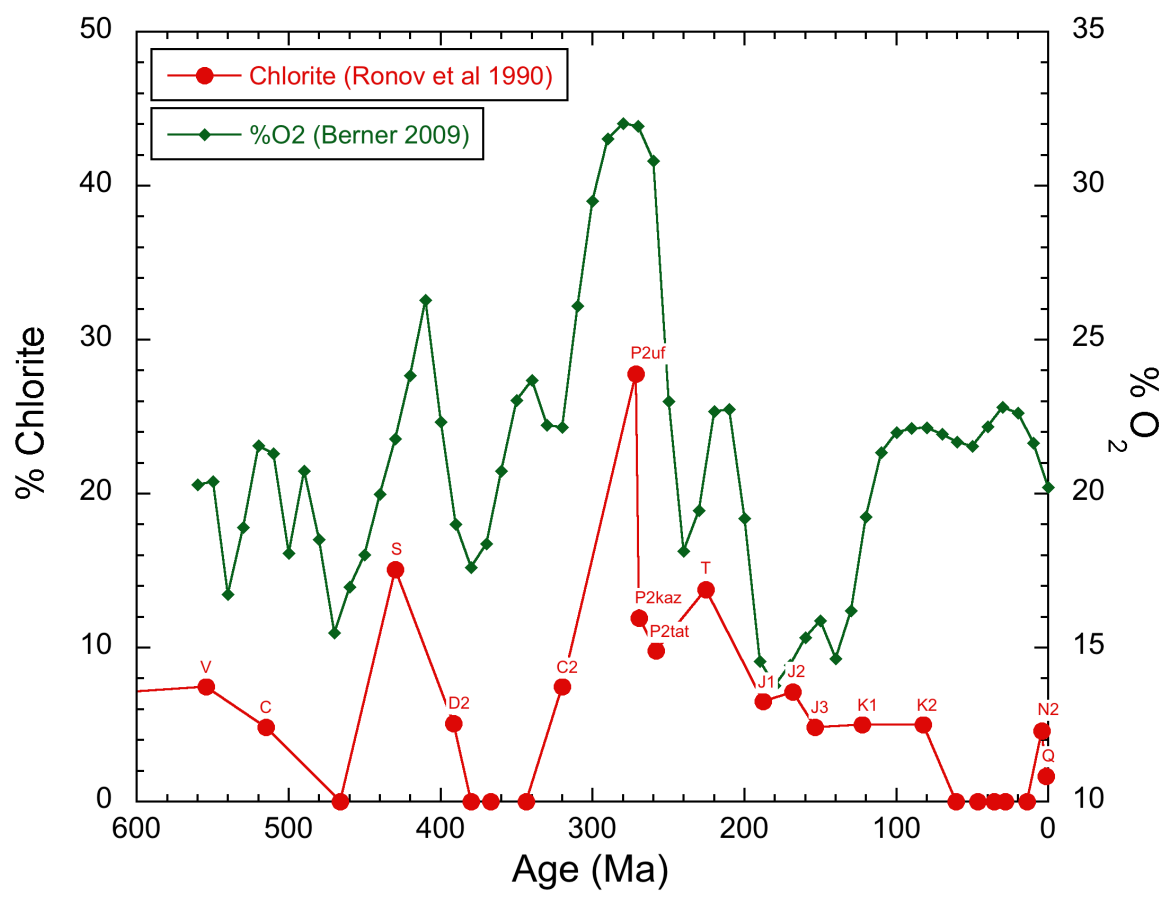

